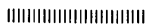

\title{
アルミニウムのリサイクルー二次合金地金
}

下村 勇一*

Recycle of aluminum, aluminum secondary alloy ingot

Yuichi SHIMOMURA*

\section{1. 歴史と背景}

素材産業は，どちらかといえば，縁の下の力持ちと称 されるように，時代の先端産業分野に，産業の“米”（鉄 が日本の産業の米と称されているように）を提供するこ とを最大の使命としている。

この数年来，リサイクルの優等生として，世間から熱 い眼差で見られるようになったアルミニウムの生いたち は，ちょらど今から，100年前の明治20年頃から始まる ものの，再生地金が産声をあげたのは，今から60年ほど 前の昭和の初めであった。昭和10年代は，一次製鍊の勃 興期に当たり，昭和 20 年代になって，再生地金が，鍋 · 釜を主体に使われだし，当時の再生地金の品位は，97\% アップ（水筒や弁当箱等の屑を原料），93\%アップ（合 金の板屑を原料)，90\%アップ（鋳物材の屑を原料）の 3 つがあった。また，昭和 30 年には，アルミニウム再生 地金の JIS 化が図られると同時に，この30年代には，ダ イカスト用合金が，国内で，凄まじい汪どの勢いで使わ れるよらになった。これは, 主として日本の自動車会社 が戦後の本格的生産を開始し，ダイカスト用再生地金が 多量に用いられたことによる。そして，遂に昭和 39 年に 国内でアルミニウム再生地金の生産が10万トンを超え, それ以後は年率10\%を超える勢いで自動車・建築・運輸 を中心に伸び続け，昭和62年には，100万トンを超え， 平成 3 年度の生産は予想で110万トンに迫らんとしてい る1) (図 1参照)。

この間にも, 再生地金といら呼称が二次地金および二 次合金地金と改称され（昭和40年），品質管理に必要な 機器であるカントレットが導入され (昭和 41 年頃), 昭 和45年頃からは公害対策が進められ，昭和49年には社団 法人日本アルミニウム合金協会が設立される等して，二

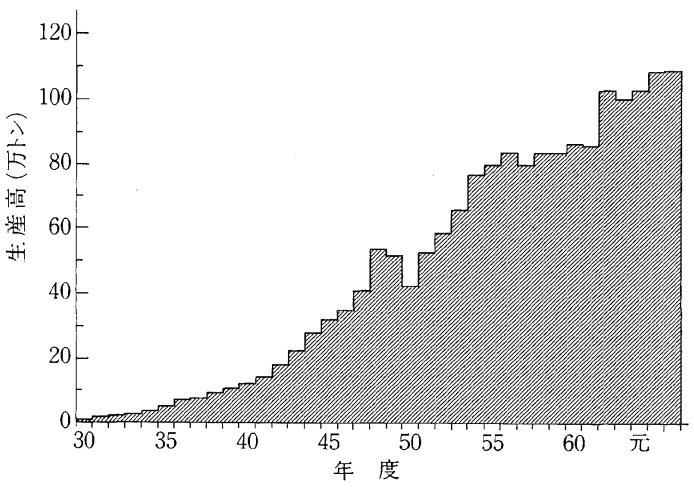

図 1 アルミニウム二次合金地金の生産高

次製錬業界の急速な発展の基礎固めが行われた。昭和50 年代に入り，オイルショック後の国内は，経済的にも自 由圏経済の仕組みの枠内で動かざるを得ない状況にな り，国内アルミニウム一次製錬の撤退，新塊地金，アル ミニウム屑の輸入拡大へと展開した。製品規格（JIS） の面でも, ダイカスト用地金については, 従来の一次 · 二次の呼称を廃止して，一本化した規格に改訂された (平成 2 年)。

\section{2. アルミニウム屑原料}

アルミニウムリサイクルの循環サークルを図 2 に示 す。この図から，アルミニウム製品の消費 $\rightarrow$ 寿命（即 ち，屑の発生）から始まり，回収 $\rightarrow$ 集荷 $\rightarrow$ 合金精錬 $\rightarrow$ 鋳 造 $\rightarrow$ 加工 $\rightarrow$ 組立 $\rightarrow$ 消費へと循環するアルミニウムのリサ イクルの全容を把握することができる。図 3 には，アル ミニウム屑およびインゴットの流通経路図を示す。これ によれば，アルミニウム 2 次製品および 3 次製品として

* 日本軽金属(侏)三重工場 (上野市)。Nippon Light Metal Co., Ltd., Mie Works (Ueno-shi, Mie). 受理日：平成 4 年 5 月 8 日 


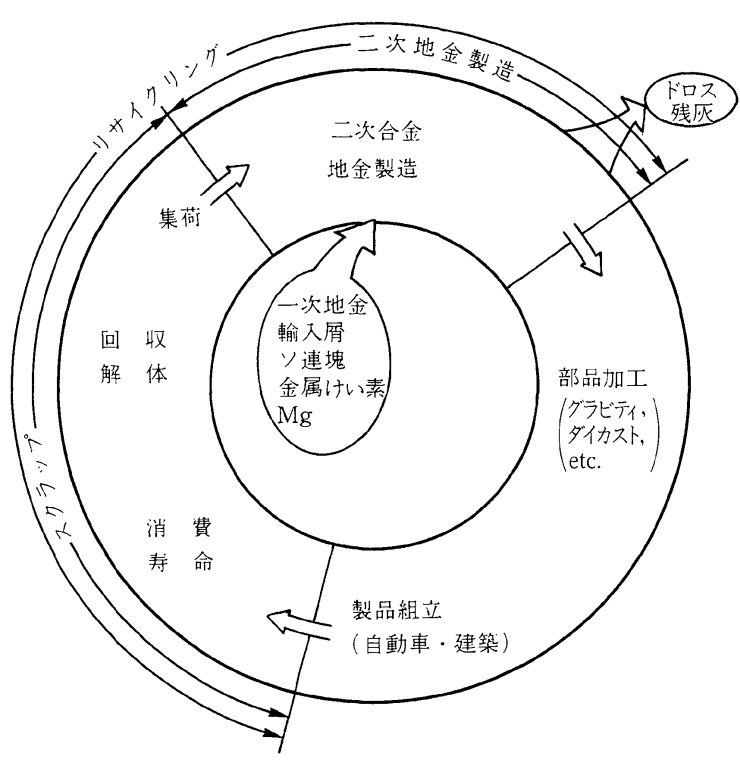

図 2 アルミニウムリサイクルの循環サークル

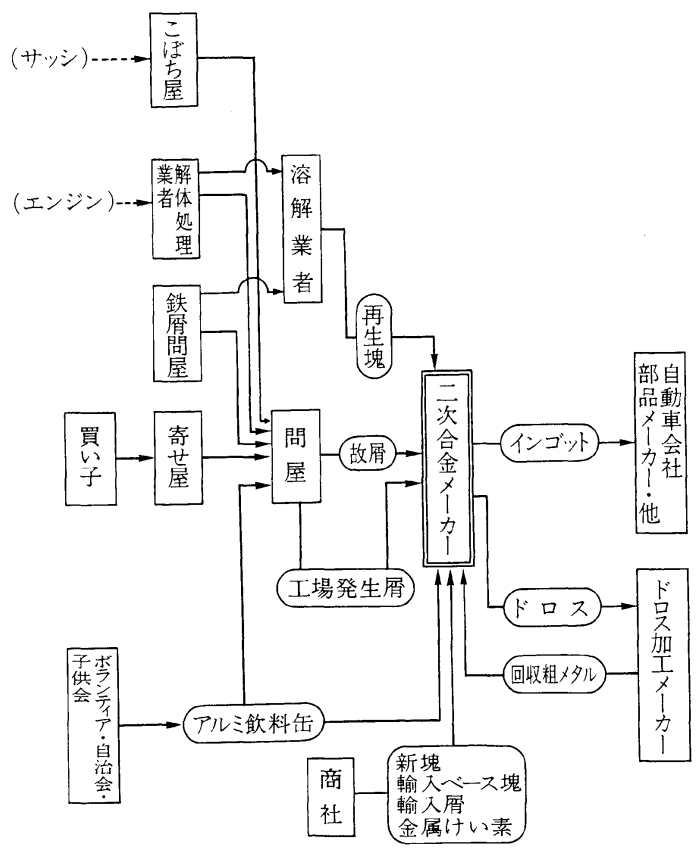

図 3 アルミニウム屑およびインゴットの流通経路 図

消費されたスクラップが, 解体の手間をかけ, 回収·集 荷され，二次合金メ一カに入ってくるのに実に多くの流 通段階を経ており，そこにはいくつもの流通経路が複雑 に存在している。たとえば，アルミ飲料缶については， これらの人々の力により，アルミ缶消費量16万トンのう

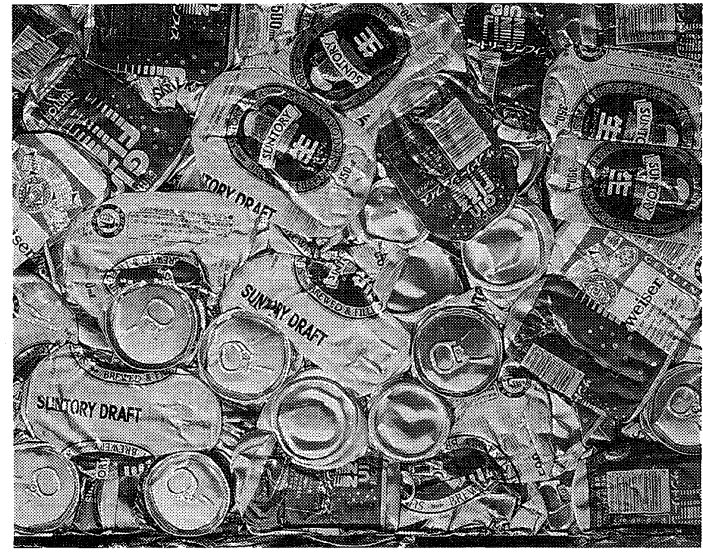

図4 回収されたアルミ缶。写真のものは, プレス されている

ちの約 $43 \%$ に当たる 7 万トンが故屑として回収・集荷さ れてくるのである2（平成 2 年度実績，図 4 )。

昨年（平成 3 年）の暮から，今年（平成 4 年）の始め にかけて, 国内スクラップの相場が值下りしたように, たとえば，キカイコロが，持ち込み価格で，キログラム 当たり105円になったとすると, 解体処理業者は, 自動 車エンジンの解体にかける手間代の方がアルミニウム屑 売值よりも高くつくといら逆ざや現象のため, 解体処理 を行わなくなり，手間のかかるスクラップは，回収され なくなってしまら。

アルミニウム屑についての中味は深く，たとえば，日 本工業規格では, JIS H2119にアルミニウム屑およびア ルミニウム合金屑分類基準が設けられており，米国で は，古くから，NARI 規格で，鉄屑・非鉄金属㞕の分類 規格を行っていたが，1988年に，これが，ISRI 規格3) にとって変わり，現在もISRIで行われている。ISRI 規 格の特徵は, アルミニウム屑の名前を, いずれも“ $\mathrm{T}$ ” を頭文字として書き記すといらもので，割合覚えやすい ものである。

表 1 には，代表的な国内屑と輸入屑との対比と，それ ら屑の特徵が書かれており，これらの屑の名前の由来に ついて調べていくと，実に面白い話に行き当たる。鋳物 屑が『コロといら名前（新コロ，キカイコロ）なのは, 姿・形がさ吕吕宅市からであるとか，『ノべ』は， 展伸故屑で，形が伸びるためであるからとか，数々の由 来がある。

日本とアメリカとでは，スクラップの回収・集荷の方 法は異なるが，日本では，買い子，寄せ屋と呼ばれる人 達が回収し, 問屋（ディーラ）に集荷して，そこから， 二次合金メ一カへ持ち込むといらルートがあり，キカイ コロ，ノベ，ガラは，多くこのルートに乗ってリサイク 
表 1 代表的なアルミニウム屑の分類

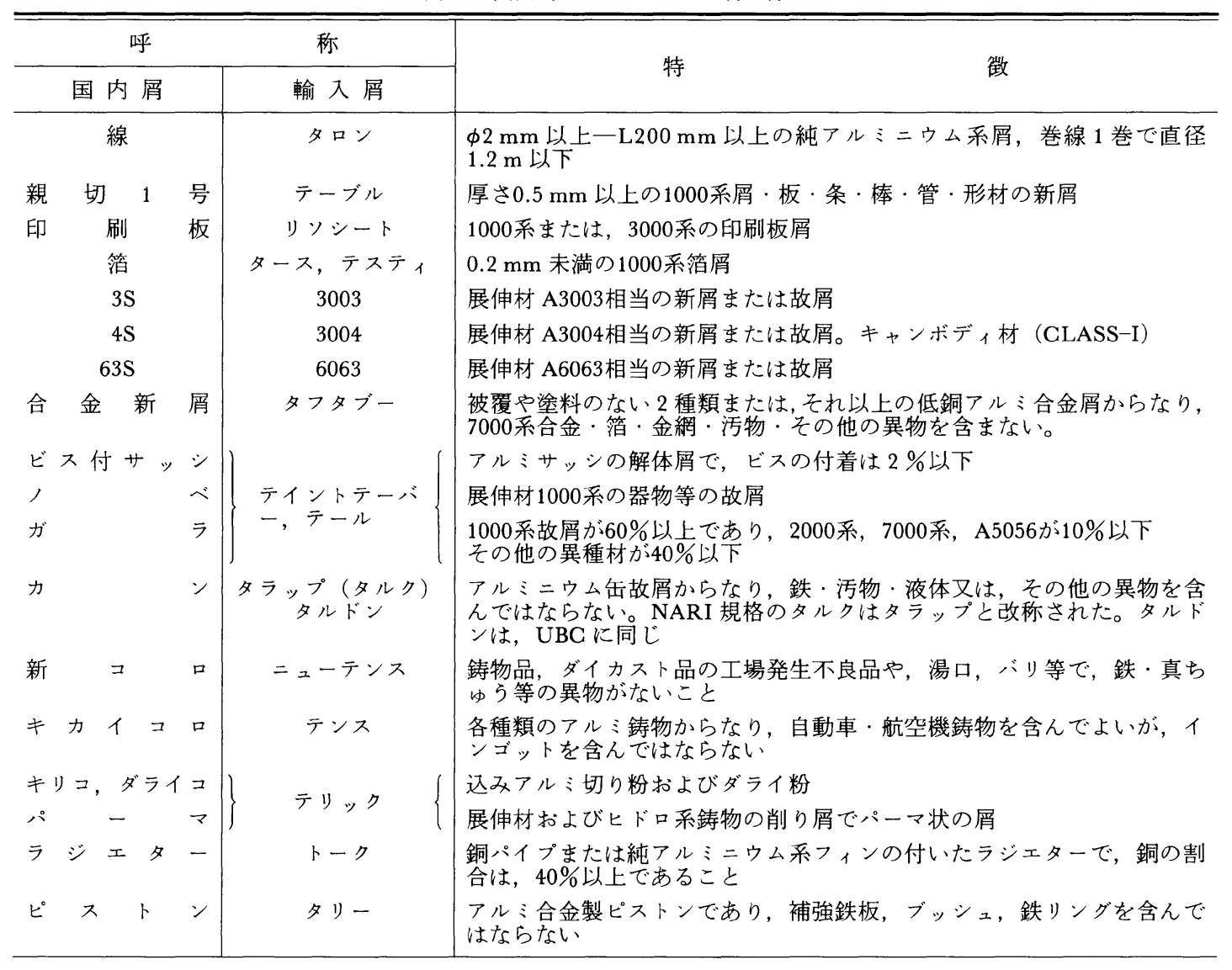

ルされるものである。また, アルミニウム缶のように， それの70\%近くが, ボランティアグループ, 自治会, 子 供会によって回収され，問屋を経て集荷されるもの，ま た，工場発生屑のように，工場から問屋を経て集荷され るもの等々がある (図 5 参照)。

これらのスクラップは, 分類基準に従った品位に応じ て分類され，持ち込まれるので，二次合金メーカではス クラップ受入れ基準に基づき検収し，その成績を相場に 加味しながら值段決定が行われる。図 3 の各流通部門間 での屑取引きは，汪とんどが現金支払いで行われる。

スクラップの回収量は, アルミ消費量とともに, 年々 多くなる一方であるが，これらの回収・集荷を担ってい る人々の働きがあってこそ廃棄物が有価物化するのであ るから，スクラップは今後とも有限な材料として考える 必要がある。また, 回収率を向上させるために, 行政と メーカがスクラップ回収に, 責任ある施策を講ずること が望まれるし，さらに一方では，大資本がスクラップの 集荷・解体選別を行い屑の合理的な処理（生産）を行う ことも今後は必要であろら。最近では, 廃車のカーシュ

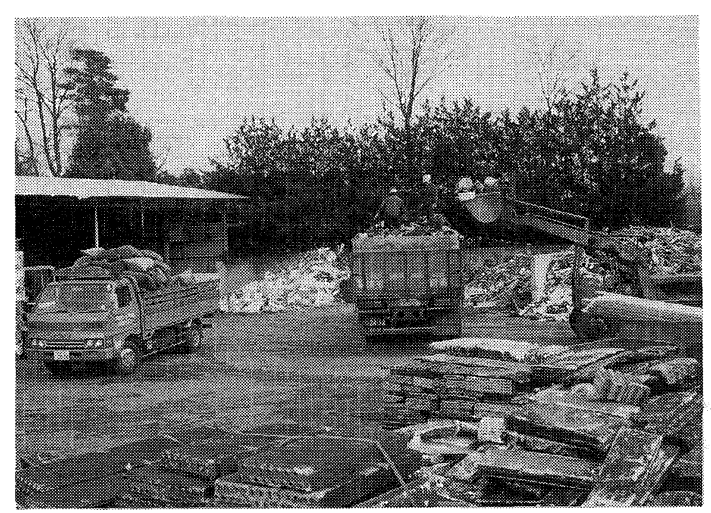

図 5 問屋を経て，二次合金メ一カに持ち込をれた アルミ屑。屑の種類毎に区別され，検収を受 ける

レッドがこのルートに乗っているようである。

\section{3. 原材料前処理}

スクラップには，前章で述べたよらに，様々な形態の 
ものがある。たとえば，鉄付きの故屏（ビス付きサッ シ, キカイコロ等）は，そのままで溶解すると溶湯へ鉄 が溶け込むので，原材料前処理として，シュレッダにか けて，40〜70 mmに細かく破砕し，その工程で分離し た鉄を磁選機により除去して，溶解しや寸いようにする 方法が取られる。アルミニウムの飲料缶は, リサイクル しやすい材料であり，今後，ますます消費量が増えてい くであろらが，溶解するとさの問題点は塗料が激しく燃 え，そのとき発生する媒塵が，作業環境を悪化させるこ とである。その対策としては，デュータ（表面塗料焙焼 装置）により前処理をして，あらかじめ塗料を取り除 き，溶解するという手順を取る。

また，故屑中には鉄以外にも，ステンレス，ごみ，木 片，プラスチック，ゴム等の異材質が混入されているも のがあるので，これらのものを前処理で除去するため に, 故屑をシュレッダした後, 渦電流選別機*1を通し て，これらの異材質をアルミニウムと分離選別するとい ら方法が取られる。さらに, 故屑中に, 亜鉛, マグネシ ウム, 真ちゅうが混入している場合, それらの異質金属 の除去のため, 故屑をシュレッダした後, 砂鉄を含んだ 重液と称するメディアの中に通過させ，それら金属とメ ディアとの比重の差でもって，アルミニウムの中から， 亜鉛, マグネシウム, 真ちゅら等を分離するといらプロ セスも採用されていて，主としてカーシュレッドの最終 選別工程に，本法（重液選別法）が用いられている。

\section{4. 溶解工程}

二次合金メーカで使われている溶解炉には，前炉付き 反射炉, 密閉式反射炉, ドライハース, 回転炉, ポット 炉, 誘導炉があり, 熱源としては, 重油, 灯油, LPG, 都市ガス, 低周波誘導起電力が挙げられる。スクラップ 溶解の最大のポイントは, 安全に溶解することと歩留を 高く留めることにある。この条件に適合し，しかも生産 性が高い溶解炉としては，前炬付き反射炉（オープンウ ェル炉) が挙げられるが，オープンゥェル炉は，昭和35 年に日本に導入されるや否や4), 急速に広まっていっ た。屑の浸漬溶解の方法としては, 図6のように, フォ ークリフトに押込工具を取り付け，作業者がリフトを運 転しながら溶解していくといらのが一般的である。スク ラップの溶解は, 暑熱環境の中で安全と歩留を確保しな がら行われる過酷な作業であり，かつ高度なスキルが要

*1 ベルトを介して, 高速回転する磁極回転子上を流 れるアルミニウムは, 高周波交播磁界を受ける結 果, アルミニウム内部に渦電流が発生し, 磁極回 転子との間で回転遠心方向への斥力を生ずること により, アルミニウムが飛び出し, 異材質と選別 を可能にする。

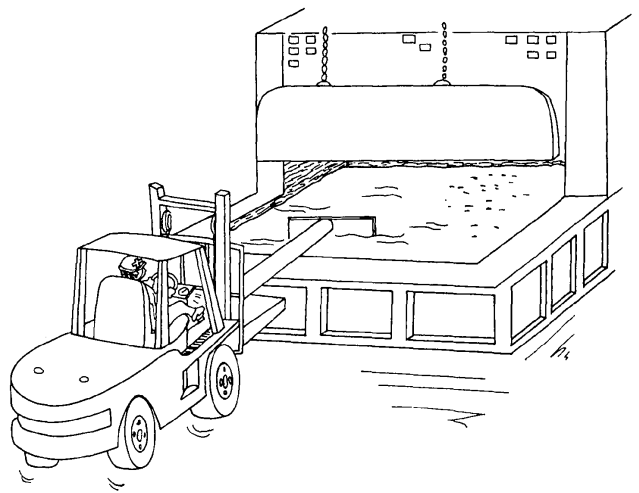

図6オープンウェル炬でのアルミニウム屑の溶解

求される方法に頼っている。

しかし，最近では，熟練者の高龄化対策， $3 \mathrm{~K}$ 職場の 改善対策として，機械装置により屑の自動溶解を試みる ことが起こってきている。ただし，形状や特徽が異なる 種々の屑をいくつかにパターン化したとしても，全部の 屑を完全に自動溶解することは無理が伴うので（精巧な 機械装置ほど，炉の熱で，作動部が故障して使えなくな る)，材料の特徵をよく探んだ上で自動化の条件に適合 する屑のみに限定して自動溶解を行らとい5ものであ る。たとえば,シュレッダしたシュレッド屑を溶湯中に 浸漬した回転子に定量供給して，連続的に自動溶解する 方法が普及しつつある。

そもそも屑といらものは, 表面に塗料, ビニール, 油 が付いていたり, 表面処理が施されていたり, 酸化腐食 していたりするものの集合体であるので，溶解時に媒塵 やドロスが発生するのが普通である。そこで, 媒塵に対 しては, 洰布式集塵機や電気集塵機により捕集を行い, 公害対策・作業環境対策を施し，かつまた安全保護具の 装着により粉塵・媒塵の人体への吸入防止を図るなど, 作業者の健康に対する配慮がなされている。またドロス については，炉から掬き上げた状態では，ドロス中に随 伴メタルが30〜 60\%近くあるので, MRM（灰较り機） により，機械的に，ドロスとメタルとを分離し，絞った メタルは炉に戻し，残灰ドロスはただちにスキムクーラ で泠却し，最終的に灰加工メーカに売却される（委託加 エしている場合には, 灰加工メーカで, ドロスより回収 された粗メタルを，二次合金メ一カが買い戻すことにな る)。ところが, 灰加工メーカで, 加工を終わった最終 残灭は, 一部鉄鋼向けの保温材として利用されるもの の, その量は年間10万トン程度でしかなく, 年間20万ト ンもの量が廃棄物として埋立て処分されているのが現状 である5)。

屑を全部溶解した後に溶湯の成分分析を, 発光分析機 
により行い（中間分析），分析結果に基ついて補正を行 5。目標とする成分規格より組成が高い元素について は, 適切な材料で薄め, また, 組成が低いものについて は，添加材や母合金等を追加投入して，規格に合致する ように造り込む。配合で, 溶湯組成が規格組成になるよ らにコントロールしているが，屑溶解の場合は，補正は 欠かせない作業である。ラウタル合金や，ADC10， ADC12では，けい素成分は金属けい素，銅成分につい ては，銅製のラジェタ一屑を添加することとしている。 また，マグネシウムの規格オーバに対しては, 塩素ガス またはフラックスにより脱 $\mathrm{Mg}$ を行らのが一般的であ る。最終的に, 確認分析を採り溶製工程に入る。

\section{5. 溶製工程（精錬工程）}

溶製工程（精錬工程）では, 溶湯を一端高温にして添 加材の溶解を完全に行らのと同時に, 脱涬フラックスを 投入して擋找しながら，酸化物の分離を完全に行う。こ のとき，溶製工程でさばきが不充分な場合，ドロスが然 焼して（急激に酸化する）, 電気玉が生成しやすいので, 擋拌後, 速やかに涬を怇外に出して, 冷灰を加えながら MRM で扊絞りを行ら。フラックスの投入量は，ドロ スの状態によっても異なるが，一般に溶湯重量の 0.05 $0.1 \% く ら い て ゙$ 行われる。

次に, 溶湯中に溶解しているガスを除く処理（脱ガス 処理）を行ら。アルミニウム溶湯中には，溶解䨌囲気に よっても異なるが, 一般に, 水素, メタン, 炭酸ガス, 一酸化炭素等のガスが溶解している。それらの中でも, 水素が最も多く, 80 95\%の割合を占める。脱ガス処理 の方法としては, 炉中溶湯へ, ランスを介して, 塩素が ス, 窒素ガス, またはアルゴンガスを吹込む方法や，フ ラックスフィーダによってフラックス吹込む方法, さら には，ガス吹込みの回転ノズルを付帯したインライン脱 ガス装置による脱ガス方法等がある。これらのなかで, 最も脱がス効果があるのは, インライン脱ガス法であ り，それは，鋳造中に気液接触時間が $2 \sim 4$ 分となるよ うに設計された容量の溶湯処理槽に, アルゴンと塩素の 混合ガスを回転子のノズル先端より吹込み, 脱ガス処理 するといら方法である。このとき, 出側のガス量は $0.1 \sim 0.2 \mathrm{ml} / 100 \mathrm{~g} \mathrm{Al}$ 程度に脱ガスされる。一方, 窒素 ガスで炉内脱ガス処理したときは, 条件により多少異な るが，30分間の脱がス処理で， $0.3 \mathrm{ml} / 100 \mathrm{~g} \mathrm{Al}$ がおお よその飽和点であろう。脱ガス後は, 溶湯温度を鋳造温 度に管理しながら（脱ガス処理後は, 極力加熱燃焼を避 けるべきである）鎮静保持をして，その後に鋳込みを開 始する。

\section{6. 鋳 造工程}

鋳造工程は，先の溶製工程で炉内精錬された溶湯を出 湯口を経て連続したインゴットケースに流し込み，凝固 させ， 1 本が $5 \mathrm{~kg}$ の重さのインゴットを造ることにあ る。ここでの管理項目は，鋳造時の溶湯温度と鋳造速度 （インゴットケースの送り速度）である。鋳造温度が基 準温度より高い場合は，炉内および樋中で水素ガスの再 吸収を受け，凝固過程でインゴットにガス気泡を発生さ せる原因になるので好ましくない。逆に，低い場合は溶 湯が分配機（インゴットケースへの溶湯分配ドラム）内 で固まりだして，鋳造不能となる。いずれにしても，鋳 造温度は地金の品質を造り込む上で最重要項目である。

鋳造速度は, 凝固時間が品種によって異なる点と, 凝 固収縮率が品種によって異なるため,ケースからの脱型 タイミングが違らといら 2 点で, 規定される。一般的に は，一つの鋳造機で時間当り7〜10トンのインゴットが 固められる (図 7 参照)。

最近は鋳造機を 2 機同時に稼働させ，炉内の溶湯を 2 機の鋳造機に分けて出湯させることが多く行われてい る。これは，生産性向上の意義も大きいが，1口ットが 40〜60トンのメタル容量の鋳造では時間がかかるので, できる限り短時間に鋳込んで組成の変動 $(\mathrm{Mg}$ や $\mathrm{Ca}$ が 減耗し易い)，ガスの再吸収によるガス含有量の増大を 避けることにより，ロット内の品質ばらつきを抑占込む 上でも重要な意味あいがある。

1 本が $5 \mathrm{~kg}$ のインゴットを井桁に積み上げ，台脚用の 足インゴットを組合わせて相包し，品種名等客先指定の 表示を行った後, 最終工程で外観検査および出荷分析検 査を行い，手配に従って出荷または倉庫入れされる（図 8 参照)。

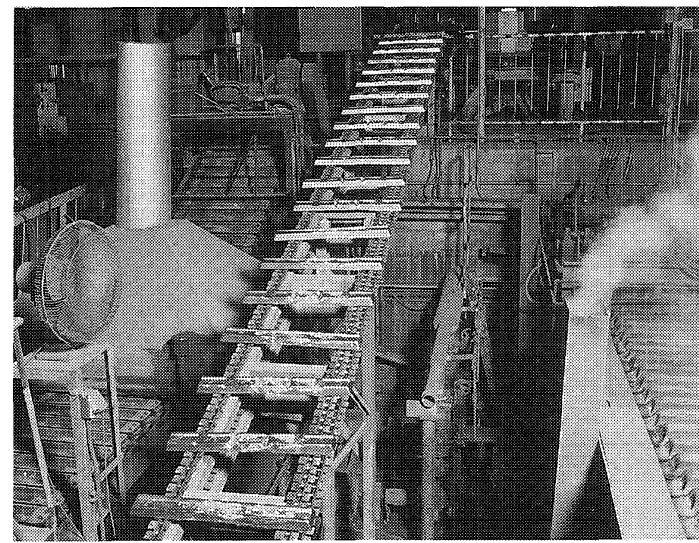

図7インゴットケースから脱型され，積上機まで 冷却されながら運ばれるアルミニウムインゴ . 


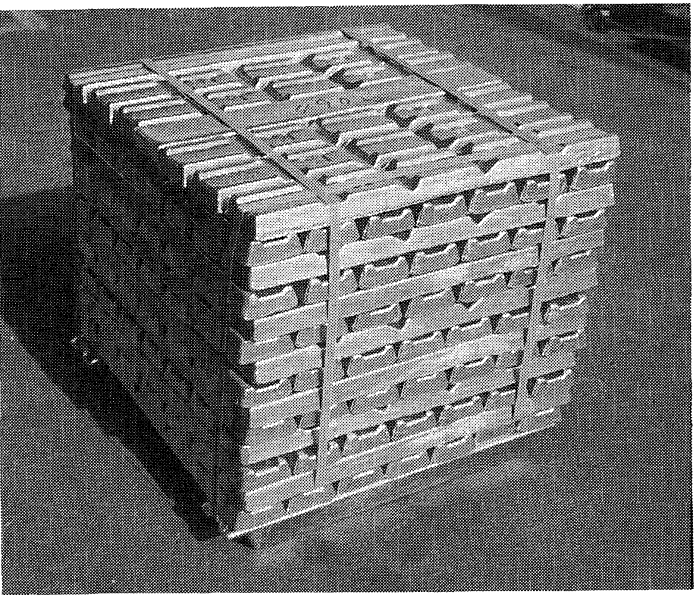

図 8 最終検査を経て出荷される製品インゴット (写真は，100本で 1 梱包となり，重量は500 $\mathrm{kg}$ のの)

\section{7. 品質管理と技術開発}

二次合金地金の製造では微量成分を含め，主要成分を 組成規格に合致させるための成分管理と溶湯の温度管理 が最も重要な品質管理項目といえる。しかし, 最近の鋳 物用アルミニウム合金においては，地金の内部品質につ いても介在物量およびガス含有量の低い地金が要求され ており，それらの品質の造り込みのために，以下に述べ る処理と品質管理が行われる。

まず，介在物除去については，鋳造中に樋にセットし たセラミックフィルタまたはガラスフィルタによって， 溶湯中の異物 · 介在物の除去を行ら。地金中の介在物量 に関する品質評価法は, 一般にフィルタ通過後の溶湯を サンプリングしてKモールドに鋳造し，そのサンプル 中の介在物欠点数により, 溶湯の清浄性を評価する方法 を適用している6)。

また，地金のガス含有量を低く抑えた造り込みは，先 に述べたような脱ガス処理によるものであるが，ガス含 有量の品質評価法としては, 減圧凝固法またはテレガス によるガス量測定法がある。ただし，減圧凝固法は限度 見本との照合による等級評価法であるので, 精度に関し ては若干ラフである。ランズレー式ガス分析法は，古典 的なガス量評価法の一つであるが，結果が出るまでの時 間が長すぎるので，ごくまれな場合を除き，合否判定に は用いられていない。

二次合金地金の多くの用途は自動車部品であるが，た とえば，シリンダヘッド，インテークマニホールドの鋳 造では徐冷部の引け巣発生が問題となるため, 引け特性 のよい（耐圧性の優れた特性を有する）地金が必要とな
る。そのために，二次合金メーカでは，溶湯のきめ細か い管理を行っている7)。さらに，溶湯の評価手段とし て, 示差熱分析をマイコン装置で行ら方法も開発されて いる。

新合金の開発については, 要求特性に影響を及ぼす成 分について水準数をいくつか設定しておき，試作試験を 行い, 熱処理をも含めて機械的特性を評価していく。最 終的に需要家との間で設定される規格は, 経済性も加味 した上で決められる。なお, 新合金の開発の際, 耐食性 についても重要な特性值の一つとして評価することを忘 れてはならない。

最近は自動車産業を中心に, アルミニウム合金の採 用，VAによる一次合金から二次合金への転換の動きが 活発であることから，二次合金地金の需要は年率 4〜5 \%の勢いで伸びており，今後さらにアルミニウムリサイ クル推進のブームに乗って, 各産業分野でますます増え ていくものと考えられる。

アルミニウムリサイクリングで最も障害となるのは, アルミニウム屑に混入する鉄である。前処理工程で，ど んなに鉄除去に努めても100\%取り除くことはできず， 何らかの量の鉄が溶解工程で溶湯中に溶け込み, Fe 組 成が高くなる。鋳物用合金地金では，Feが低いほど品 質は高いのであるが，Feが不可避的に高くなった溶湯 では，凝固組織中に， $\mathrm{Al}-\mathrm{Fe}-\mathrm{Si}$ 針状晶出物が現われる ため, 強度・伸びの低下, さらに機密を要求される部品 では，圧洩れを起こす。この問題に対しては，現在，種 々の研究が行われている。

\section{8. おわりに}

二次合金業が細々とした粗メタル製造業からスタート して, 昭和 39 年の 10 万トンを超えた頃から, 昭和 62 年の 100万トンに到達した間の生産量の増加率は年10\%とい ら急激な伸びを示している。かくも二次合金生産量の飛 躍的な伸びが見られたのは，需要家の要望する地金の品 質とコストを追求することをモットーに，品質管理の導 入によるJIS マーク表示に関する認可審査に代表される ように，積極的な生産管理の姿勢があったからである。

国内で，アルミニウム一次製鍊が，わずか日本軽金属 蒲原製造所を残すだけとなった今日，合金地金は二次製 鍊が，すでに主導権を握っており，各企業とも，西歴 2000年を展望した二次合金製造プラントを建設する気運 が高まりつつある。恐らく, 5〜 10年後には, 徐々に溶 解現場から作業者がいななり，クーラの効いた部屋か ら，溶解作業をオペレートするよらな工場が出現してく ることであろう。そのときには, この職場は, 昔は $3 \mathrm{~K}$ の代表のようにいわれていたものだったと，懐かしい思 い出話となることを夢みて著者も頑張りたい。最後に, 
本記事が現場的内容に片寄ってしまったことを御容赦願 いたい。

\section{参 考 文 献}

1）非鉄金属の需給：資源統計年報，通産省（1991）, 6.

2）アルミ缶リサイクル協会発行資料による（平成 2 年
度)

3）米国アルミニウムくず（ISRI）規格表（昭和63年 9 月 1 日改正), 日本アルミニウム合金協会

4）大信洋行 50 年史による（昭和 35 年発刊）

5）梅原茂雄：Al一ある，8（1991），10.

6）「Kモールド試験法」（実用新案 昭52-17449）

7）「耐圧性に優れた鋳物用アルミニウム合金」（公開特 許公報, No. 平1-156446) 